\title{
INEEL Summary On Calcination
}

\author{
Dr. Dirk Gombert, P.E.
}

December 2002

Idaho National Engineering and Environmental Laboratory Bechtel BWXT Idaho, LLC 


\section{INEEL Summary of Calcination Operations}

\section{Including:}

1. A brief summary of operations and the current calcine inventory

2. Safety issues of the process.

3. Current liability and hindsight evaluation of choice to calcine.

4. Long-term plans and cost-effectiveness of calcination as an interim solution?

By

Dr. Dirk Gombert, P. E.

December 4, 2002 
INEEL Calcination Summary for UKAEA

History

Irradiated nuclear fuel reprocessing to recover ${ }^{235} \mathrm{U}$ and ${ }^{80} \mathrm{Kr}$ began at the INEEL in 1953 . The resulting acidic high-level liquid radioactive waste (HLW) was stored in stainless steel tanks in underground concrete vaults. A fluidized-bed calcination process was developed during the 1950s to form a granular calcine solid from the acidic HLW with a seven-fold volume reduction. An engineering-scale demonstration, the Waste Calcining Facility (WCF) was constructed and operated in 1963. After the successful demonstration of the process, the WCF was continued as a production facility through 1981, Calcining $15,000 \mathrm{~m}^{3}$ of HLW to $2,160 \mathrm{~m}^{3}$ of calcine. ${ }^{1}$ The New Waste Calcining Facility (NWCF) was designed and constructed based on the operating experience of the WCF, and began operation in 1982 . With a rated capacity of 3,000 gallons/day, the NWCF continued waste processing operations through May of 2000, resulting in an additional 2,226 $\mathrm{m}^{3}$ of calcine (total current inventory of $\left.4,386 \mathrm{~m}^{3}\right)^{2}$

During waste processing at the NWCF, sodium-bearing waste (SBW) from decontamination activities was blended with HLW to minimize alkali (sodium and potassium) concentrations in the calciner feed solution. This was necessary due to the propensity of sodium and potassium nitrates to melt in the calciner, causing the bed to agglomerate and interfere with fluidization. However, near the end of HLW processing, work was initiated to modify the calcination process to treat SBW directly, blending it with chemical additives such as aluminum nitrate rather than lower alkali content HLW liquids. The result of this development effort was to increase the operating temperature of the calciner from $500^{\circ} \mathrm{C}$ to $600^{\circ} \mathrm{C}$. The $600^{\circ} \mathbf{C ~ S B W}$ flowsheet was successfully demonstrated at the NWCF during two separate trials during 1999 and 2000. ${ }^{3,4}$ The conclusion from these demonstrations was that operating the existing $\mathrm{NWCF}$ at $600^{\circ} \mathrm{C}$ is a viable method for solidifying SBW, and this concept is currently being evaluated as one option for preparing the SBW for disposal.

To restart the NWCF for SBW processing, applicable environmental waste processing and/or air permits will be required. It is anticipated that the NWCF will be regulated as an incinerator; thus, compliance with maximum achievable control technology (MACT) emission limits will be required. To meet these stringent standards, an upgrade to the off-gas treatment train will be required. Specifically, emission of $\mathrm{CO}$, total hydrocarbons (THC), and mercury must be mitigated. In addition, $\mathrm{NO}_{\mathrm{x}}$ abatement is necessary to eliminate interferences with the instrumentation required for air monitoring to demonstrate compliance.

The Waste Calcining Process

The calciner is a cylindrical fluidized-bed reactor that utilizes air as the fluidizing gas. The reactor consists of three primary sections: 1) the plenum and fluidization grid, 2) the fluidized bed reaction zone, and 3) the solid/gas disengaging section.

In the lowest reactor section, preheated fluidization air enters through the plenum in the bottom of the vessel and is routed through a fluidizing grid (distribution plate) into the main section of the reactor.

\footnotetext{
${ }^{1}$ Dieter A. Knecht, et al, "Historical Fuel Reprocessing and HLW Management in Idaho," Radwaste Magazine, Vol. 4, No. 3, May 1997, pp. 35-45.

${ }^{2}$ Idaho National Engineering Laboratory, Calcine Solids Storage Facilities, http://emhome.inel.gov/hlw/Bins/Bininvt2.htm, Web page updated March 8, 1999, Web page visited July 31, 2002.

${ }_{3}^{3}$ M. C. Swenson, New Waste Calciner High Temperature Operation, INEEL/EXT-2000-01004, September 2000.

${ }^{4}$ R. A. Wood, NWCF High-Temperature Calcination Trial Summary, INEEL/EXT-01-00851, July 2001.
} 
In the middle reactor section, bed media and solid product are fluidized. Waste feed slurry is fed by gravity through a nozzle into this section of the bed. Also, kerosene and oxygen are metered into this section of the bed to facilitate in-bed combustion, thus maintaining the desired operating temperature of $\mathbf{5 0 0}^{\circ} \mathrm{C}$ or greater depending on the flowsheet in use. Because the auto-ignition temperature of kerosene is $340^{\circ} \mathrm{C}$, combustion is self-sustaining after initial bed heat up (using air preheated with electric resistance heaters) without the need for an ignition source. Dolomite is initially charged to the bed as base seed particles on which calcined waste solids will deposit. Liquid waste is then fed which continually deposits solids, both on existing particles, and spontaneously formed particles. Larger particles are reduced in size by collisions and controlled attrition to maintain the bed within the size range conducive to fluidization. As the operation proceeds, particles are removed from the bed, and the bed gradually "turns over", i.e. the waste product replaces the dolomite. The principal reactions during calcination are evaporation and thermal decomposition of the thermally labile compounds to form metallic oxides/fluorides, water vapor, and oxides of nitrogen, as shown below:

$$
\begin{array}{ll}
\mathrm{Ca}^{2+}+2 \mathrm{~F}^{-} \rightarrow \mathrm{CaF}_{2} & \text { Calcium fluoride formation } \\
\mathrm{Ca}^{2+}+\mathrm{H}_{2} \mathrm{O} \rightarrow \mathrm{CaO}+2 \mathrm{H}^{+} & \text {Calcium oxide formation } \\
\mathrm{Al}^{3+}+\mathrm{Na}^{+}+2 \mathrm{H}_{2} \mathrm{O} \rightarrow \mathrm{NaAlO}_{2}+4 \mathrm{H}^{+} & \text {Sodium aluminate formation } \\
2 \mathrm{Al}^{3+}+3 \mathrm{H}_{2} \mathrm{O} \rightarrow \mathrm{Al}_{2} \mathrm{O}_{3}+6 \mathrm{H}^{+} & \text {Aluminum oxide formation } \\
\mathrm{Na}^{+}+\mathrm{Cl}^{-} \rightarrow \mathrm{NaCl}^{2-} \rightarrow \mathrm{Na}_{2} \mathrm{SO}_{4} & \text { Sodium chloride formation } \\
2 \mathrm{Na}^{+}+\mathrm{SO}_{4}^{2-} & \text { Sodium sulfate formation } \\
3 \mathrm{Na}^{+}+\mathrm{PO}_{4}^{3-} \rightarrow \mathrm{Na}_{3} \mathrm{PO}_{4} & \text { Sodium phosphate formation } \\
2 \mathrm{~K}^{+}+\mathrm{SO}_{4}^{2-} \rightarrow \mathrm{K}_{2} \mathrm{SO}_{4} & \text { Potassium sulfate formation } \\
3 \mathrm{~K}^{+}+\mathrm{PO}_{4}^{3-} \rightarrow \mathrm{K}_{3} \mathrm{PO}_{4} & \text { Potassium phosphate formation } \\
\mathrm{Zr}^{4+}+2 \mathrm{H}_{2} \mathrm{O} \rightarrow \mathrm{ZrO}_{2}+4 \mathrm{H}^{+} & \text {Zirconium oxide formation } \\
\mathrm{H}^{+}+\mathrm{NO}_{3}^{-} \rightarrow \mathrm{HNO}_{3} & \text { Nitric acid formation }
\end{array}
$$

In addition to the reactions shown above, kerosene combustion will also generate $\mathrm{CO}_{2}, \mathrm{H}_{2} \mathrm{O}$ and products of incomplete combustion.

The highest portion of the reactor is larger in diameter than the middle portion, resulting in a reduced gas velocity in this section. The reduction in gas velocity causes larger entrained solid particles to disengage from the gas stream and fall back into the reaction zone. Gas phase $\mathrm{NO}_{\mathrm{x}}$ formation reactions can also occur in the disengaging section of the reactor. A potential simplified reaction scheme for $\mathrm{NO}_{\mathrm{x}}$ formation is presented below:

$$
4 \mathrm{HNO}_{3} \rightarrow 4 \mathrm{NO}_{2}+\mathrm{O}_{2}+2 \mathrm{H}_{2} \mathrm{O} \quad \text { Nitric acid decomposition }
$$


$2 \mathrm{NO}_{2} \rightarrow 2 \mathrm{NO}+\mathrm{O}_{2}$

Nitrogen dioxide decomposition

Product Removal, Separation, and Packaging

Solid product is removed from the calciner by two pathways. First, fine particulate (nominally $<\mathbf{0 . 1}$ $\mathbf{m m}$ diameter) is elutriated out the top of the reactor with the fluidization gas. A high-efficiency cyclone separator is used to separate particles from the fluidization gas, which flow by gravity into the fines column. A valve below the fines column will allow flow of the fines into a pneumatic transfer line, which conveys the fines to storage.

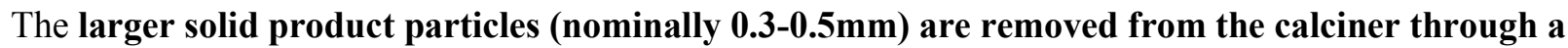
side withdrawal system. This calcine product flows into the same pneumatic transfer line used for fines transport, thus transporting both the primary product and the fines product to stainless steel storage bins in concrete vaults. Transfer air is separated using a cyclone mounted above the bins, and routed back to the upper section of the calciner.

\section{Characterization}

At the INEEL, calcine compositions are grouped into four primary groups, typified by the compositions in Table 1. The first three are named after the fuel-reprocessing operations that produced the waste, and the fourth is primarily from decontamination operations. The table lists only the non-radioactive elements, the compounds and oxides of which make up about 99 weight percent of the calcine. The radioactive isotopes make up only about one percent of the solids, because the reprocessing operations at the INEEL were based on total dissolution of the fuel, rather than a chopping and leaching process. Typical activity levels are about $\mathbf{1 0} \mathbf{~ m C i /} \mathbf{m l} \pm \mathbf{5 0 \%}$ depending on the age of the fuel at the time of reprocessing, and about $98 \%$ of this activity can probably be attributed to cesium and strontium. Calcination of SBW will produce material 10-100 times less radioactive.

\begin{tabular}{|l|c|c|c|c|}
\hline \multicolumn{5}{|l|}{ Table 1. Typical Calcine Compositions (excluding oxides) in Weight Percent. } \\
\hline Type & Aluminum & Zirconium & Fluorinel & Sodium Bearing \\
\hline Element & & & & \\
\hline Aluminum & 87.3 & 11.8 & 6.5 & 53.4 \\
\hline Sodium & 1.4 & & 4.1 & 11.4 \\
\hline Nitrate & 2.6 & 0.1 & 8.1 & 23.0 \\
\hline Boron & 0.4 & 1.1 & 1.0 & 0.8 \\
\hline Calcium & & 37.7 & 31.9 & 4.0 \\
\hline Iron & 0.1 & 0.3 & 0.2 & 0.4 \\
\hline Fluoride & & 30.1 & 21.9 & 1.0 \\
\hline Mercury & 5.5 & & & 0.003 \\
\hline Potassium & 0.1 & 0.1 & 0.9 & 2.5 \\
\hline Zirconium & & 18.2 & 15.5 & 0.3 \\
\hline Sulfate & 1.5 & & 3.7 & 1.4 \\
\hline Phosphate & 1.1 & & & 0.7 \\
\hline Chloride & & & 0.1 & 0.4 \\
\hline Tin & & 0.3 & 0.2 & 0.1 \\
\hline Chromium & & 0.4 & 0.1 & 0.2 \\
\hline Cadmium & & & 5.5 & \\
\hline
\end{tabular}

The volume reduction produced by calcination can be calculated in several ways. A simple comparison using the volume of liquid fed to the calciner versus the volume of solids sent to the 
bins yields an average volume reduction of about 6.9 over the 37 years of operation at the INEEL. However, operations generally require some decontamination activities, which generate liquid wastes that are returned to the tank farm. Thus, the net reduction in the liquid waste inventory is reduced, resulting in a net volume reduction of about 5.9. These calculations include all feed additives such as additional calcium or aluminum nitrates to complex the fluorides in the wastes to minimize corrosion. Thus, about 7.8 million gallons $(30$ million liters) of liquid waste have been processed, resulting in about 150,000 cubic feet $\left(4,200 \mathrm{~m}^{3}\right)$ of calcine in storage.

Safety

Calcination is obviously a thermal process using combustion of kerosene. The wastes being processed are nitric acid-based, highly radioactive, and some solutions contain appreciable hydrofluoric acid complexed with calcium and/or aluminum. Thus, the typical industrial hazards of flammable mixtures, heat, acids, and oxides of nitrogen are present and complicated by the remote operations necessitated by the radioactivity. On the other hand, the remote operations, and the New Waste Calciner Facility, which is designed for remote maintenance, isolate the operators from most of the industrial hazards. The potential for an explosive mixture exists, but the fuel system is interlocked to ensure the calciner vessel is above the autoignition temperature for kerosene before the fuel can be added, and operation is monitored to maintain significant excess oxygen.

Before contact maintenance can be initiated, decontamination may be required to reduce expected radiation exposure levels to allowable limits, and systems must be purged of corrosive solutions and toxic gases. Adequate personal protective equipment is required to maintain the safety envelope for all activities.

The other primary hazard identified has been related to the proposed use of ammonia for reduction of oxides of nitrogen (NOx). Not only is anhydrous ammonia a significant hazard in itself, it can combine with the NOx to form ammonium nitrate, a shock sensitive material that can be hazardous if it is allowed to build up in containment. This is one reason why steam reforming and higher temperature thermal reduction of the NOx using a fuel are being considered as alternative NOx abatement processes.

\section{Current Liability}

The INEEL currently stores about $4,200 \mathrm{~m}^{3}$ of calcine and about 3.8 million liters of SBW. The calcine is a dry solid stored in stainless steel bins, contained in concrete vaults. The vault and calcine temperature and vent radiation levels are continuously monitored. The SBW liquid is stored in stainless steel tanks monitored for corrosion. Both represent a long-term liability in that neither are considered ultimate disposal, but the State of Idaho shows a much stronger concern for the potential spill of liquid waste and possible contamination of the aquifer over 300 feet below the tank farm.

The long-standing baseline for HLW disposition in the US has been vitrification as a borosilicate glass. Processing rates are greater for direct vitrification of dry calcine, but a flowsheet has also been demonstrated for redissolving calcine for feeding as a liquid to maintain a "cold-cap". A non-vitrification alternative is also being considered in which the calcine would be shipped to a 
federal geologic repository as is, or with only a stabilizing matrix to change the form of the material from a finely divided particulate to a non-flowing solid. Thus, calcine does not present any particular disadvantages for disposal.

Certainly, conveying the calcine after many years of storage could be a concern compared to pumping a liquid. Some of the calcine bins have registered centerline temperatures in excess of $600^{\circ} \mathbf{C}$, though limited sampling showed that the recovered material could still be pneumatically conveyed. More problematic may be the retrieval process, particularly in the earlier bins. Limited access was provided in the original designs, and internal supports and vessel curvature will complicate a remote vacuuming concept. Calcine surrogate retrieval mockups have shown that the calcine will probably support a negative angle of repose, so a retrieval nozzle will probably have to articulate in several directions and fluidize the material around it.

The design challenges posed by the calcine inventory must be compared to the relative concerns of liquid storage. Had the calcination process not been used, the current tank farm including eleven 330,000-gallon tanks (10 in use and one spare, for a total working volume of three million gallons) would have had to be expanded by at least 28 more tanks of comparable size. This many tanks would have been required to store the waste that has been calcined, and to segregate different solutions to preclude undesirable chemical reactions. Though there has never been a leak from one of the INEEL HLW tanks, there have been leaks from the interconnecting piping resulting in contaminated soil in the current tank farm. A larger, more complex tank farm would have probably resulted in additional contaminated soil. Further, had the decision been made to neutralize the waste in a manner similar to the practice at Savannah River and Hanford, the waste volumes would be increased significantly as well as producing copious metal hydroxide sludges. Not only would neutralization have resulted in more waste volume, the ultimate decontamination of the tanks would have been far more complex, versus the relatively simple decontamination flushing operations now underway at the INEEL. The costs of the additional tank farm capacity is probably easily offset by the cost of the calciner and calcine storage facilities, but the trade-off for long-term risks of storage of dry solids versus corrosive liquids probably favors the decision to calcine the waste.

$\underline{\text { Path Forward }}$

The immediate priority is on preparing the SBW inventory for disposal and emptying of the tank farm by 2012. Vitrification is still the baseline for HLW, but the SBW is being evaluated for classification as "waste incidental to reprocessing" because it is primarily from decontamination activities rather than first-cycle raffinate. Several options are being considered including: 1) upgrading the calciner to process the SBW under current air emission standards and direct packaging the product for shipping, 2) fluidized-bed steam reforming, a similar process to denitrify and result in a dry product, but without the combustion of kerosene, 3) direct evaporation to solid salts, and grouting of the distillate, and 4) cesium removal by ion exchange followed by stabilization of the residual liquids. The current effort including piloting some of the options to support conceptual designs will yield better estimates on ultimate costs, as well as defining areas of concern for process implementation. The budget ranges from \$200 to 400 million for the project costs, with the calciner upgrade and operation presumably near the lower end of that range because most of the facilities already exist. 
The long-term disposition of the calcine is covered by a commitment to the State of Idaho to have the material ready to ship by 2035. Judging by the significant modifications made to the Hanford Waste Treatment Plant projected budget, any estimate for future calcine disposal costs would be of debatable value. If the waste is to be vitrified, the calcine can be fed directly or redissolved or slurried to be pumped to a melter as described above. If the waste is to be grouted, the nitrates that would likely limit the waste loading for a liquid have been destroyed by calcination, and a non-thermal stabilization process would be enhanced. If calcine can be disposed directly, the dry powder could be packaged loose, compacted to reduce packaging volume, or stabilized in a solid matrix. The primary complication would be retrieval from the bins, and the complexities arise not from calcination but in not designing the storage bins for retrieval. 